\section{Assessment of Bone Healing in Rabbit Calvaria Grafted with Three Different Biomaterials}

\author{
Carlos Alberto Yoshihiro Takauti ${ }^{1}$, Fabio Futema², Rui Barbosa de Brito \\ Junior $^{3}$, Aline Corrêa Abrahão ${ }^{4}$, Claudio Costa ${ }^{5}$, Celso Silva Queiroz ${ }^{6}$
}

\author{
'Master's Program in Dentistry, \\ UNIP - Paulista University, \\ São Paulo, SP, Brazil \\ ${ }^{2}$ Department of Veterinary \\ Medicine, UNIP - Paulista \\ University, São Paulo, SP, Brazil \\ ${ }^{3}$ Department of Dentistry, São \\ Leopoldo Mandic Institute and Dental \\ Research Center, Campinas, SP, Brazil \\ ${ }^{4}$ Department of Dentistry, UFRJ \\ - Federal University of Rio de \\ Janeiro, Rio de Janeiro, RJ, Brazil \\ ${ }^{5}$ Department of Stomatology, School \\ of Dentistry, USP - University of \\ São Paulo, São Paulo, SP, Brazil \\ ${ }^{6}$ Department of Dentistry, \\ Veiga de Almeida University, \\ Rio de Janeiro, RJ, Brazil \\ Correspondence: Dr. Carlos Alberto \\ Yoshihiro Takauti, Rua Arcângelo \\ Corelli, 72, 02463-100. São Paulo, \\ SP, Brasil. Tel: +55-11-2231-1284, \\ e-mail: carlostakauti@yahoo.com.br
}

Key Words: biomaterials, bone regeneration, xenogen bovine graft, alloplastic graft.

\section{Introduction}

The use of osseointegrated dental implants requires an adequate amount of bone tissue both in volume and in quality (1). However, these conditions are not always available, necessitating reconstruction with bone substitutes. Autogenous bone is regarded as the gold standard for these procedures because of its biological and physico-chemical properties, which are considered optimal (2). However, there is a need for a second surgical procedure, increasing the risk of complications (3). The bone allograft presents a reduction in surgical procedures (4), although there are risks such as disease transmission (5). Because of these difficulties, many biomaterials of xenogenous or alloplastic origin are being researched for the purpose of bone reconstruction.

Xenogenous bovine bones are used as bone substitutes, they are deproteinized and lyophilized. Biomaterials with these characteristics do not cause any immune response, so they are considered as biocompatible (6). This category includes Bio-Oss ${ }^{\circledR}$ (Geistlich-Pharma, Wolhusen, Switzerland), consisting of calcium carbonate apatite; it is osteoconductive, has a porosity between $75 \%$ and $80 \%$ and can be used to raise the maxillary sinus membrane, resulting in proper osseointegration of the dental implant in the bone tissue (7). Bio-0ss ${ }^{\circledR}$ is slowly reabsorbed, with residues found nine years after the initial graft (8).

Endobon ${ }^{\circledR}$ Xenograft Granules (RegenerOss ${ }^{\mathrm{TM}}$, BIOMET $3 \mathrm{i}$, Palm Beach Gardens, FL, USA) are another bone substitute consisting of bovine bone, both deproteinized and lyophilized. According to the manufacturer, it is granular in form, has a porosity between $45 \%$ and $80 \%$ and consists of completely deproteinized hydroxyapatite bovine. Moreover, it is biocompatible, bioactive, osteoconductive and not resorbable $(9,10)$.

Straumann ${ }^{\circledR}$ Bone Ceramic (Biora $A B$, company of the Straumann Group, Malmoe, Sweden) is a fully alloplastic bone substitute based on biphasic calcium phosphate ( $40 \% \beta$-tricalcium phosphate and $60 \%$ hydroxyapatite), it is osteoconductive and is used to raise the maxillary sinus membrane surgery (11), results in trabecular bone structure with close contact with the biomaterial, thereby allowing the placement of dental implants after six months (12).

The aim of this study was to evaluate and compare bone healing in surgically prepared cavities in rabbit skulls using three different biomaterials, two of which are xenogenous, consisting of deproteinized and lyophilized bovine bone, and one alloplastic bone based on biphasic calcium phosphate.

\section{Material and Methods Experimental Design}

Three bone substitutes were used, as follows: two xenogens consisting of deproteinized and lyophilized bovine bone in Bio-Oss ${ }^{\circledR}$ and Endobon ${ }^{\circledR}$ Xenograft Granules, and a fully alloplastic one based on biphasic calcium phosphate in Straumann ${ }^{\circledR}$ Bone Ceramic. They were surgically grafted into 
bone defects prepared in the skullcaps of five rabbits. After eight weeks, the samples were subjected to morphometric and qualitative analyses. For the statistical analysis, ANOVA and Tukey's test were conducted at a significance level of 0.05 using the statistical software SAS version 7.0 (SAS Institute, Cary, NC, USA).

\section{Animal Study}

The present study used five New Zealand male white rabbits, weighing between $2900 \mathrm{~g}$ and $3500 \mathrm{~g}$. The study was approved by the ethics committee (protocol $n^{\circ} 011 / 12$ CEP/ICS-UNIP) and was in accordance with the guidelines and rules for research involving animals according to State Law no. 11997 of August 25, 2005, which established the Code of Animal Protection of the State of São Paulo, Brazil.

The animals were kept in individual cages under the same environmental conditions before surgery and during the evaluation period. They were fed MP872 (Moinhos Primor S.A., São Paulo, SP, Brazil) and water ad libitum.

\section{Surgical Procedures}

Surgical procedures followed previously proposed methodologies by Aghaloo et al. (13). The animals were premedicated using a combination of $1 \mathrm{mg} / \mathrm{kg}$ of morphine (Cristália Produtos Químicos Farmacêuticos Ltda., Itapira, SP, Brazil), $1 \mathrm{mg} / \mathrm{kg}$ of midazolam (Cristália Pridutos Químicos Farmacêuticos Ltda., Itapira, SP, Brazil), $10 \mathrm{mg} / \mathrm{kg}$ of ketamine (Symtec do Brasil Ltda, Cotia, SP, Brazil) and $2 \mathrm{mg} /$ kg of xylazine (Rompun ${ }^{\circledR}$ Bayer S.A., São Paulo, SP, Brazil) administered intramuscularly. Anesthesia was induced with propofol (Cristália Produtos Químicos Farmacêuticos Ltda., Itapira, SP, Brazil) at a dose of $2 \mathrm{mg} / \mathrm{kg}$ intravenously, as well as local anesthesia with $4 \%$ articaine hydrochloride with 1:100,000 epinephrine (DFL Industria e Comercio S.A., Rio de Janeiro, RJ, Brazil), via infiltration at the site of surgery. Throughout the procedure, the animals were masked to provide $100 \%$ oxygen; they were monitored for heart rate, respiratory rate, oxygen saturation, hemoglobin, temperature and blood pressure (BP) (systolic BP, diastolic $\mathrm{BP}$ and $\mathrm{PA}$ average) in a non-invasive way with a veterinary multiparameter monitor (NeoVet ${ }^{\circledR}$, Centaurus Medical, San Diego, CA, USA). Prophylactic antibiotic therapy was administered with enrofloxacin (Schering-Plough Saúde Animal Ind e Com Ltda, Cotia, SP, Brazil) at a dose of 5 $\mathrm{mg} / \mathrm{kg}$ intravenously.

After obtaining anesthesia, the surgical region was shaved and applied with 2\% iodine antiseptic solution. Next a sagittal incision was made approximately $10 \mathrm{~cm}$ in the midline of the skull, primarily in the skin, followed by the periosteum to expose the parietal bones. Four standardized bone defects were made, two on each bone, using a sterile 8-mm diameter trephine cutter drill (Implacil Material
Odontológico Ltda., São Paulo, SP, Brazil) under copious irrigation with sterile saline solution.

The defects were filled with different bovine bone substitutes. First was filled with Bio-Oss ${ }^{\circledR}$ of diameters between 250 and $1000 \mu \mathrm{m}$. The second was filled with Endobon ${ }^{\circledR}$ Xenograft Granules of diameters between 500 and $1000 \mu \mathrm{m}$. The third was filled with Straumann ${ }^{\circledR}$ Bone Ceramic, a completely alloplastic-based biphasic calcium phosphate comprising $60 \%$ hydroxyapatite (HA) and $40 \%$ $\beta$-tricalcium phosphate ( $\beta$-TCP), of diameters between 500 and $1000 \mu \mathrm{m}$. One of the defects was maintained as control (Fig. 1).

Grafting procedures were performed before the periosteum was repositioned absorbable suture (Vicryl ${ }^{\circledR}$ 4-0, Johnson \& Johnson do Brasil Indústria e Comércio de Produtos para Saúde Ltda, São José dos Campos, SP, Brazil). Then, the skin was repositioned and sutured with nylon thread (5-0 Ethicon ${ }^{\circledR}$ Johnson \&t Johnson do Brasil Indústria e Comércio de Produtos para Saúde Ltda, São José dos Campos, SP, Brazil). After suturing, the surgical region was washed with $2 \%$ iodine solution.

After completing the surgical procedures, xylazine reversal was induced through the antagonist yohimbine (PowerVet, São Paulo, SP, Brazil) at a dose of $0.1 \mathrm{mg} / \mathrm{kg}$ intravenously. Immediate postoperative analgesia was administered via intramuscular morphine at $1 \mathrm{mg} / \mathrm{kg}$.

Postoperatively, the animals were administered the analgesic tramadol hydrochloride (Cristália Produtos Químicos Farmacêuticos Ltda., Itapira, SP, Brazil) at 0.6 $\mathrm{mL} / 12$ in $12 \mathrm{~h}$, the anti-inflammatory drug dexamethasone (disodium phosphate) at $0.6 \mathrm{ml} / 12$ in $12 \mathrm{~h}$ over three days, and the antibiotic enrofloxacin $2.5 \%$ at $0.6 \mathrm{~mL} / 12$ in 12 $\mathrm{h}$ for one week.

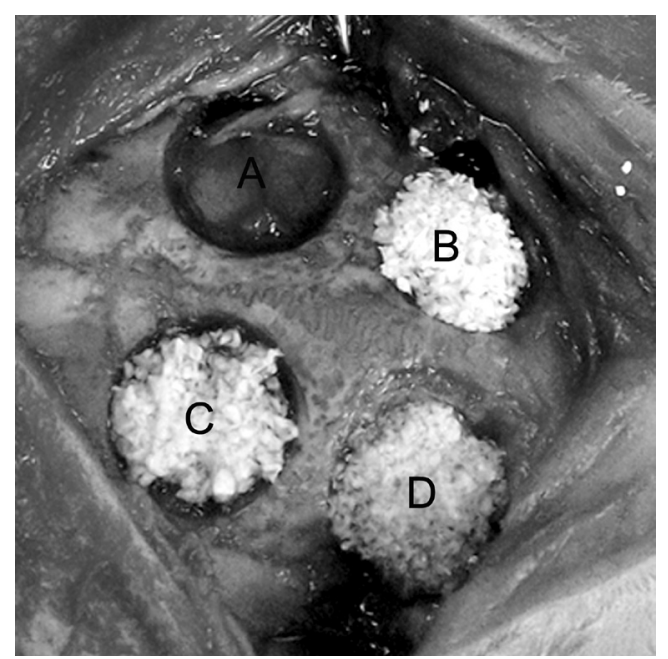

Figure 1. Defects in the parietal bone patterned and filled with graft materials. A: Control, B: Straumann Bone Ceramic, C: Bio-Oss ${ }^{\oplus}$ and D: Endobon ${ }^{\mathbb{*}}$ Xenograft Granules. 


\section{Sacrifice of Animals}

The animals were sacrificed eight weeks after the surgical procedures, initially using a combination of xylazine $(20 \mathrm{mg} / \mathrm{kg})$ and ketamine $(50 \mathrm{mg} / \mathrm{kg})$ administered intramuscularly, followed by $25 \mathrm{mg} / \mathrm{kg}$ of sodium thiopental (Cristália Produtos Químicos Farmacêuticos Ltda, Itapira, $\mathrm{SP}$, Brazil) administered intravenously in the ear vein 15 minutes thereafter.

\section{Histological Analysis}

The samples were demineralized in 20\% formic acid for seven days, dehydrated in alcohol with increasing concentrations $(70 \%-100 \%)$ for one hour each, cleared in two changes of xylene for one hour each and were paraffin embedded at $60^{\circ} \mathrm{C}$ for $1 \mathrm{~h}$. Five micrometers were obtained, stained with hematoxylin and eosin (HE) and analyzed using light microscopy.

\section{Morphometric Analysis}

Five sections $(5 \mu \mathrm{m})$ were obtained from the center of each sample from each animal (20x magnification). Histology slides were then obtained for histomorphometric analysis coded to be blind regarding study treatment groups. We used a system of computerized image analysis consisting of a light microscope (Axioskop 2 plus ${ }^{\circledR}$, Carls Zeiss, Oberkochen, Germany) coupled to a camera (Axio
Cam HRc ${ }^{\circledR}$, Carls Zeiss, Oberkochen, Germany) connected to a microcomputer, which used the image analysis software Axion Vision ${ }^{\circledR}$ rel 4.8 (Carls Zeiss, Oberkochen, Germany). Percentages were calculated for newly formed bone, residual graft and connective tissue in the bone marrow.

\section{Qualitative Analysis}

Qualitative analysis of the samples was conducted using cone-beam computer tomography obtained with the scanner Gendex $\mathrm{CB}^{2} 50^{\circledR}$, (Gendex Dental Systems, Des Plaines, IL, USA) under the following settings: 120 $k V p$, voxel $0.125 \mathrm{~mm}$ and acquisition time of $23 \mathrm{~s}$. For the three-dimensional reconstructions, the software INVIVO $5^{\circledR}$ (Anatomage, San José, CA, USA) was used, with axial DICOM thickness of $1 \mathrm{~mm}$.

\section{Statistical Analysis}

The histomorphometrlc data showed homoscedasticity of variances after application of the $F$ test. Analysis of variance was performed, which showed differences between the treatments at a significance level of 0.05 . Then was applied the Tukey's test, which compared the different treatments (coagulum, Bio-Oss ${ }^{\ominus}$, Endobon ${ }^{\circledast}$ Xenograft Granules and Straumann ${ }^{\oplus}$ Bone (eramic) according to different factors (newly formed bone, residual graft and connective tissue in the bone marrow). SAS 7.0 (SAS Institute, Cary, NC, USA) was used for the statistical analyses.
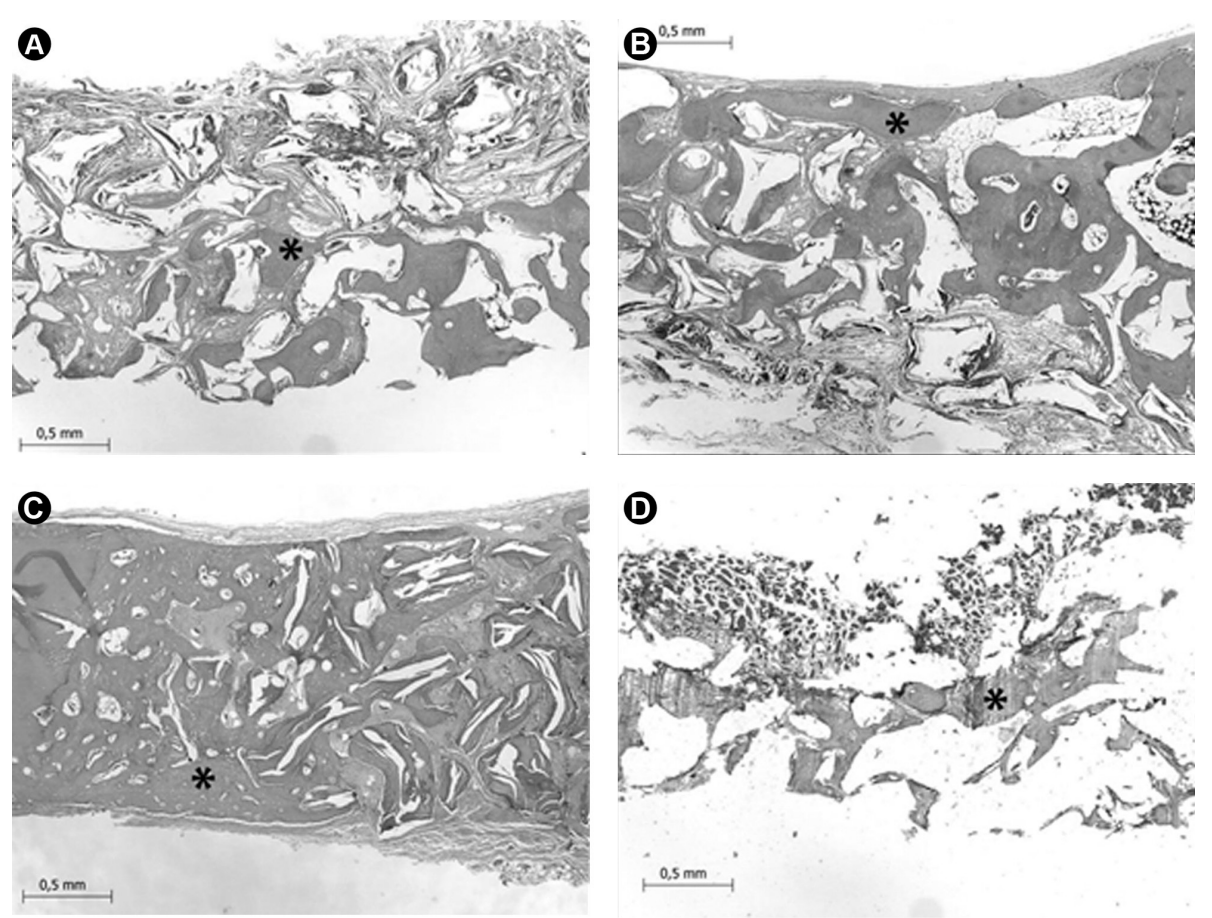

Figure 2. Bone formation in defects in the parietal bone of a rabbit filled with different biomaterials. A: Control, B: Straumann ${ }^{\infty}$ Bone Ceramic, C: Bio-Oss ${ }^{\circledast}$, and D: Endobon ${ }^{\circledR}$ Xenograft Granules (black asterisk = new bone, blue asterisk = residual graft, Original magnification, 100x; HE).

\section{Results} Histological Analysis After eight weeks, histological analysis showed the presence of new bone tissue in all cavities filled with different biomaterials. Presence of residual graft was also observed in the surgical defects filled with Straumann ${ }^{\circledR}$ Bone Ceramic and Bio-Oss ${ }^{\circledR}$ (Fig. 2).

\section{Morphometric Analysis}

Morphometric analysis showed the following amounts of newly formed bone: Bio-0ss ${ }^{\circledR}(57.00 \pm 7.76)$, End ob on ${ }^{\circledR}$ Xenograft Granules (58.42 \pm 6.29$)$ and Straumann ${ }^{\circledR}$ Bone Ceramic (78.06 \pm 8.95$)$. The percentage of new bone formation 
was greater $(p<0.05)$ in the bone defects filled with Straumann ${ }^{\circledR}$ Bone Ceramic than in those grafted with BioOss ${ }^{\circledR}$ or Endobon ${ }^{\circledR}$ Xenograft Granules (Table 1). Residual graft material displayed the following levels: BioOss ${ }^{\circledR}$ with 27.58 \pm 6.16 , Endobon ${ }^{\circledR}$ Xenograft Granules with $25.42 \pm 8.82$ and Straumann ${ }^{\circledR}$ Bone Ceramic with $6.28 \pm 1.79$, with the last one showing significantly lower levels $(p<0.05)$ (Table 1$)$. The presence of connective tissue in the bone marrow was not significantly different ( $p>0.05$ ) among the biomaterials used for filling bone defects (Table 1).

\section{Qualitative Analysis}

The qualitative analysis was based on images of threedimensional reconstructions obtained by cone-beam computer tomography. They showed that the cavities filled with Bio-Oss ${ }^{\circledast}$ and Endobon ${ }^{\circledast}$ Xenograft Granules presented higher hyperdensity and better homogeneity. Cavities

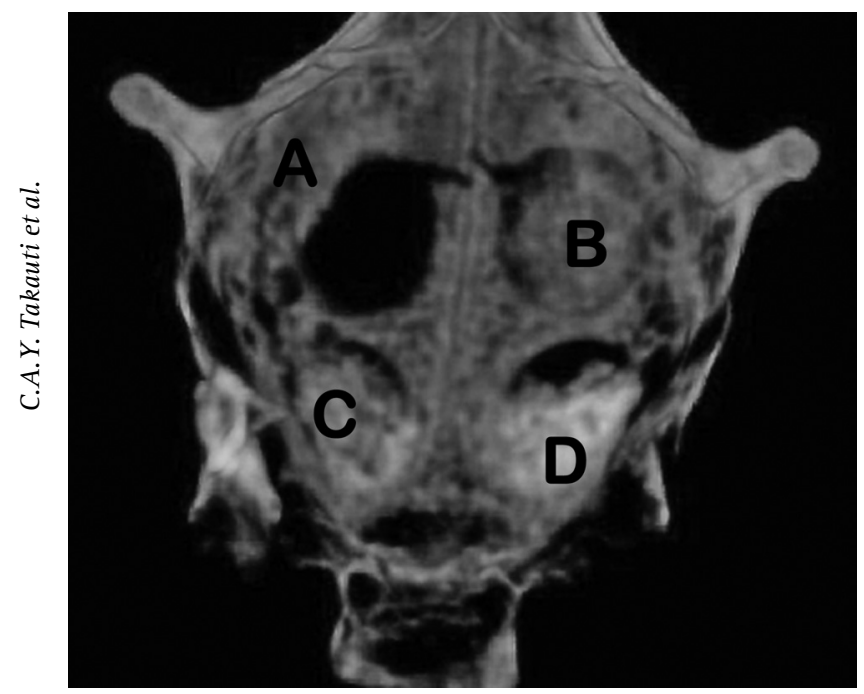

Figure 3. Three-dimensional reconstruction obtained from conebeam computer tomography showing repaired cavities. A: control, B: Straumann ${ }^{\circledR}$ Bone Ceramic, C: Bio-Oss ${ }^{\oplus}$ and D: Endobon ${ }^{\circledast 2}$ Xenograft Granules.

Table 1. Mean and SD values in percentages (\%) of bone neoformation, residual graft and connective tissue in the bone defects, using different biomaterials after 8 weeks.

\begin{tabular}{lccc}
\hline$\%$ & $\begin{array}{c}\text { Neoformation } \\
\text { of bone }\end{array}$ & Residual graft & $\begin{array}{c}\text { Connective } \\
\text { tissue }\end{array}$ \\
\hline Control & $77.80 \pm 5.50 \mathrm{a}$ & $\mathrm{N} / \mathrm{A}$ & $27.90 \pm 5.50 \mathrm{a}$ \\
Bio-0ss & $57.76 \pm 7.75 \mathrm{~b}$ & $27.58 \pm 6.16 \mathrm{a}$ & $14.74 \pm 7.54 \mathrm{~b}$ \\
$\begin{array}{l}\text { Endobon Xenograft } \\
\text { Granules }\end{array}$ & $58.42 \pm 6.29 \mathrm{~b}$ & $25.42 \pm 8.82 \mathrm{a}$ & $16.16 \pm 6.10 \mathrm{~b}$ \\
$\begin{array}{l}\text { Straumann } \\
\text { Ceramic }\end{array}$ & $78.06 \pm 8.95 \mathrm{a}$ & $6.28 \pm 1.79 \mathrm{~b}$ & $15.66 \pm 7.34 \mathrm{~b}$ \\
\hline
\end{tabular}

Columns with different letters indicate statistical differences (Tukey's - 0.05) $\mathrm{N} / \mathrm{A}=$ not applicable grafted with Straumann ${ }^{\circledast}$ Bone Ceramic showed greater qualitative irregularities. The control (coagulum) showed hypodense images of the defects (Fig. 3).

\section{Discussion}

When the study objective is to evaluate bone healing in an animal model using bone substitutes, it is essential to verify whether the substituted material complied with the concept of "critical size defects". This concept has different thresholds according to the animal species and the site of the defect. Using standardized defects of $8 \mathrm{~mm}$ diameters in the parietal bones of rabbit calvariae allowed large increases in their interface with bone graft materials used in this study. This was a reasonable choice with previously shown experimental results (14). This region was also important because of its similar embryological origin and morphology to the maxilla, as well as its limited anatomic area of mechanical stress and relative stability of the neighboring structures, both of which make it ideal for evaluating osteogenesis induced by biomaterials (15). A period of eight weeks was appropriate to assess late repair, including new bone tissue resorption of the graft material, bone remodeling and bone regeneration (16).

In the present study, morphometric analysis and conebeam computed tomography showed that the biomaterials induced new bone formation after eight weeks, indicating that they have osteoconductive properties. In addition, alloplastic biomaterials presented greater levels of newly formed bone in compared to deproteinized bovine bone. These results are similar to that obtained when Bio-0ss ${ }^{\circledR}$ was compared over the same observation period, which is based on biphasic calcium phosphate with the same composition (HA/ $\beta$-TCP in a proportion of $60 / 40$ ) in shapes of "donut" granules at the submicron level (i.e., from $300-400 \mu \mathrm{m}$ pores for central particles $0.8 \mathrm{~mm}$ ) (MegaGen Implant, Kyungsan, Korea) (17). However, different results were observed in studies assessing maxillary sinus membrane elevation (11, 18) and in those studying rabbit calvariae after eight weeks involving defects of standard $6.5 \mathrm{~mm}$ diameter (5). These studies found no statistically significant differences in the levels of newly formed bone tissue induced by these biomaterials.

Xenogenous biomaterials showed similar behavior, both in the amount of newly formed bone, as the amount of residual graft. The results can be explained by the origin of the materials tested, as both were of bovine origin, were deproteinized and lyophilized, had similar granule diameters (Bio-Oss ${ }^{\circledR}$, 250-1000 $\mu \mathrm{m}$ and Endobon ${ }^{\circledR}$ Xenograft Granules, 500-1000 $\mu \mathrm{m}$ ) and had similar porosity (Bio-Oss ${ }^{\circledR}$ between 75\% and 80\% 8 and Endobon ${ }^{\circledR}$ Xenograft Granules between 45\% and 85\% (BIOMET $3 \mathrm{i}^{\text {тM}}$ ). 
The results of the present study were similar to those reported by Tovar et al. (19), which compared the BioOss ${ }^{\circledR}$, OsteoGraf N-300 ${ }^{\circledR}$ (Dentsply International, York, PA, USA), and two variations a newly developed biomaterial (Dentsply International, York, PA, USA). After eight weeks of evaluation, no statistical difference in the amount of newly formed bone was observed.

The biomaterial based biphasic calcium phosphate showed a lower amount of residual grafting $(p<0.05)$ compared with bionaterials consisting of deproteinized bovine bone. The result was similar to that found in a study that evaluated the behavior of the Straumann ${ }^{\circledR}$ Bone Ceramic and Bio-Oss ${ }^{\circledR}$ in elevation of the floor of the maxillary sinus surgery (11).

Several studies have shown that the presence of residual graft when using biomaterials based on deproteinized bovine bone is due to its slow resorption $(8,10,20,21)$. Traini et al. (20) suggest that the difficulty of resorption of Bio Oss ${ }^{\circledR}$ is related to its high content of calcium and absence of proteins. In the study by Ramirez-Fernandez et al. (21), performed in tibiae of rabbits, Endobon ${ }^{\circledR}$ Xenograft Granules was less absorbable than from swine OsteoBiol ${ }^{\circledR} \mathrm{mp} 3$ (TECNOSS srl, Giaveno, Italy). In the alloplastic biomaterials based biphasic calcium phosphate (HA/ $\beta$-TCP ratio $60 / 40$ ), the $\beta$-TCP constituent is quickly resorbed and replaced with natural bone provided faster remodeling, while the HA constituent slower resorbed, allowing the preservation of the bone volume $(11,12)$. Other studies showed an increased resorption of $\beta$-TCF compared to HA (ratio $60 / 40)(22,23)$ and no change in the ratio of 20/80 (24).

Cavities filled with blood clot had morphometrically greater amount of newly formed bone tissue than the cavities filled with biomaterial-based bovine bone $(p<0.05)$ and similar to the amount found in cavities filled with biomaterial-based phosphate biphasic calcium ( $p>0.05$ ). This result was also observed by Rokn et al. (5), which suggest that this may be related to the repositioning and suturing of the periosteum during surgical procedures, acting as natural membrane, inducing guided tissue regeneration. Other studies in rabbits calvaria, also showed neformation bone tissue similar between the clot and the platelet-rich plasma (13) and between the clot and biodegradable gelatin hydrogel (25). Borie et al. (15) shows that the clot had lower bone formation compared to autogenous bone and human bone allogenic in rabbit calvaria.

Despite the differences with the control group, only the coagulum is not effective in the clinical setting. In augmentation procedures involving implant placement, thickness or height of the alveolar bone is important; as such, coagulum is less than ideal because it lacks resistance to compression from the soft tissue. For such procedures, it is essential for the graft material to have osteoconductive properties (i.e., it should be able to create structural support for new bone formation), suggesting the importance of evaluating biomaterials used for this purpose.

Three-dimensional reconstructions by cone-beam tomography showed that the cavities with bovine bone presented higher hyperdensity, more homogeneous and smaller amount of new bone, while cavities with biphasic calcium phosphate showed greater irregularities, but larger amounts of new bone. These results may be related to the greater amount of residual graft present in areas that received xenogenous biomaterials. The presence of more such biomaterials, which have slow resorption (20), could provide images with greater regularity than in areas with the greatest amount of new bone. These reconstructions have also shown that cavities with blood clot showed no filling at the center of the surgical defect. These results suggest that the newly formed bone is concentrated at the edges surgical defect, reinforcing the clinical argument that in cases of bone reconstruction a bone substitute with osteoconductive feature is necessary.

The results of this study showed that there is a need for further studies to assess biomaterials that are more effective in the process of bone induction than those used in this study. Both qualitative and quantitative techniques are warranted to better interpret the results as they relate to clinical applicability. In conclusion, the obtained outcomes suggest that all biomaterials induced bone formation after eight weeks. Although the alloplastic biomaterial induced more bone formation, further studies are essential to prove what type of biomaterials is more effective in bone induction.

\section{Resumo}

Este estudo avaliou o processo de reparação óssea induzida por três biomateriais, dois de origem xenógena constituido de osso bovino desproteinizado e um aloplástico à base de fosfato de cálcio bifásico, em calota craniana de coelhos. Em cinco coelhos brancos da Nova Zelândia com peso entre 2900 e $3500 \mathrm{~g}$, foram realizadas quatro perfurações padronizadas de $8 \mathrm{~mm}$ de diâmetro nos ossos parietais e enxertados dois biomateriais de origem bovina: Bio-Oss ${ }^{\circledR}$ e Endobon ${ }^{\circledR}$ Xenograft Granules e um totalmente aloplástico: Straumann ${ }^{\circledR}$ Bone Ceramic. Uma cavidade permaneceu com coágulo e foi utilizado como controle. Após oito semanas os animais foram sacrificados e as amostras preparadas para análise morfométrica e qualitativa. Os resultados mostraram que as cavidades preenchidas com o biomaterial aloplástico apresentaram percentualmente maior quantidade de osso neoformado $(p<0,05)$. Apesar dos resultados mostrarem maior neoformação óssea pelo Straumann ${ }^{\circledR B}$ Bone Ceramic, há a necessidade de mais estudos para se comprovar qual biomaterial é mais efetivo no processo de indução óssea.

\section{References}

1. Breine $U$, Branemark P-I. Reconstruction of alveolar jaw bone: an experimental and clinical study of immediate and preformed autogenous bone grafts in combination with osseointegrated implants. Scand J Plastic Reconstr Surg Hand Surg 1980;14:23-48.

2. Tadic D, Epple M. A thorough physicochemical characterization of 14 
calcium phosphate-based bone substitution materials in comparison to natural bone. Biomaterials 2004;25:987-994.

3. Sbordone L, Toti P, Menchini-Fabris GB, Sbordone C, Pimbino P, Guidetti F. Volume changes of autogenous bone grafts after alveolar ridge augmentation of atrophic maxillae and mandibles, Int J Oral Maxillofac Surg 2009;38:1059-1065.

4. Barone $A$, Varanini $P$, Orlando $B$, Tonelli $P$, Covani U. Deep-Frozen allogenic onlay bone grafts for reconstruction of atrophic maxillary alveolar ridges: a preliminary study. J Oral Maxillofac Surg 2009;67:1300-1306.

5. Rokn AR, Khodadoostan MA, Ghahroudi AARR, Motahhary P, Fard MJK, De Bruyn $\mathrm{H}$, et al.. Bone formation with two types of grafting materials: a histologic and histomorphometric study. The Open Dent J 2011;5:96104.

6. Zambuzzi WF, Oliveira RC, Pereira FL, Cestari TM, Taga R, Granjeiro JM. Rat subcutaneous tissue response to macrogranular porous anorganic bovine bone graft. Braz Dent J 2006:17:274-278.

7. Hallman $M$, Cederlund $A$, Lindskig $S$, Lundgren $S$, Sennerby L. A clinical histologic study of bovine hidroxyapatite in combination with autogenous bone and fibrin glue for maxillary sinus floor augmentation. Results after 6 to 8 months of healing. Clin Oral Implants Res 2001;12:135-143.

8. Traini T, Valentini P, lezzi G, Piatelli A. A histologic and histomorphometric evaluation of anorganic bovine bone retrieved 9 years after sinus aumentation procedure. J Periodontol 2007;78:955-961.

9. Spies CKG, Schnurer S, Gotterbarm T, Breusch SJ. Efficacy of Bone Source ${ }^{\circledR}$ and Cementek ${ }^{\circledR}$ in comparison with Endobon ${ }^{\circledR}$ in critical size metaphyseal defects, using a minipig model. J Appl Biomater Biomech 2010;8:175-185.

10. Ramirez-Fernandez MP, Calvo-Guirado JL, Delgado-Ruiz RA, MatéSánchez del Val, JE, Gómez-Moreno G, Guardiã J. Experimental model of bone response xenografts of bovine origin (Endobon ${ }^{\circledR}$ ): a radiological and histomorphometric study. Clin Oral Implants Res 2011;22:727-734.

11. Cordaro L, Bosshardt DD, Palattella P, Rao W, Serino G, Chiapasco M. Maxillary sinus graftting with Bio-Oss ${ }^{\circledR}$ or Straumann ${ }^{\circledR}$ Bone Ceramic: histomorphometric results from a randomized controlled multicenter clinical trial. Clin Oral Implants Res 2008;19:796-803.

12. Frenken JWFH, Bouwman WF, Bravenboer N, Zijderveld SA, Schulten EAJM, et al... The use of Straumann ${ }^{\circledR}$ Bone Ceramic in a maxillary sinus floor elevation procedure: a clinical, radiological, histological and histomorphometric evaluation with a 6-month healing period. Clin Oral Implants Res 2010;21:201-208.

13. Aghaloo TL, Moy PK, Freymiller EG. Investigation of platelet-rich plasma in rabbit cranial defects: a pilot study. J Oral Maxillofac Surg 2002;60:1176-1181.

14. Marques JM, Viegas $C_{\text {, Dias }} \mathrm{MI}$, Zagalo $\mathrm{C}_{\text {, Gomes }}$, Fernandes $\mathrm{MH}$, et al.. Modified model of sub-critical size cranial defect in the rabbit. Int J Morphol 2010;28:525-528.
15. Borie $E$, Fuentes $R$, del Sol M, Oporto G, Engelke W. The influence of FDBA and autogenous bone particles on regeneration of calvaria defects in the rabbit: A pilot study. Ann Anat 2011;193:412-417.

16. Sohn J-Y, Park J-C, Um Y-J, Jung U-W, Kim C-S, Cho K-S, et all. Spontaneous healing capacity of rabbit cranial defects of various sizes. J Periodont Implant Science 2010;40:180-187.

17. Park J-W, Kim E-S, Jang J-H, Suh J-Y, Park K-B, Hanawa T. Healing of rabbit calvarial bone defects using biphasic calcium phosphate ceramics made of submicron-sized grains with a hierarchical pore structure. Clin Oral Implants Res 2010;21:268-276.

18. Froum SJ, Wallace SS, Cho S-C, Elian N, Tarnow DP. Histomorphometric comparison of a biphasic bone ceramic to anorganic bovine bone for sinus augmentation: 6- to 8- month postsurgical assessment of vital bone formation. A pilot study. Int J Periodontics Restorative Dent 2008;28:273-281.

19. Tovar N, Jimbo R, Gangolli R, Perez L, Manne L, Yoo D, et all. Evaluation of bone response to various anorganic bovine bone xenografts: an experimental calvaria defect study. Int J Oral Maxillofac Surg 2014:43:251-260.

20. Traini T, Degidi M, Sammons R, Stanley P, Piatelli A. Histologic and elemental microanalytical study of anorganic bovine bone substitution following sinus floor augmentation in humans. J Periodontol 2008;79:1232-1240.

21. Ramirez-Fernandez MP, Calvo-Guirado JL, Delgado-Ruiz RA, MatéSánchez del Val JE, Vicente-Ortega V, Mesenguer-Olmos L. Bone response to hydroxyapatites with porosity of animal origin (porcine [OsteoBiol $\left.{ }^{\circledR} \mathrm{mp} 3\right]$ and bovine - [Endobon $\left.{ }^{\circledR}\right]$ ) a radiological and histomorphometric study. Clin Oral Implants Res 2011;22:767-773.

22. Hwang JW, Park JS, Lee JS, Jung UW, Kim CS, Cho KS, et al.. Comparative evaluation of three calcium phosphate synthetic block bone graft materials for bone regeneration in rabbit calvaria. J Biomed Mater Res B Appl Biomater 2012;100:2044-2052.

23. Hong JY, Lee JS, Pang EK, Jung UW, Choi SK, Kim CK. Impact of different synthetic bone fillers on healing of extraction sockets: an experimental study in dogs. Clin Oral Implants Res 2014;25:e30-e7.

24. Yang C, Unursaikhan O, Lee JS, Jung UW, Kim CS, Choi SH. Osteoconductivity and Biodegradation of synthetic bone substitutes with different tricalcium phosphate contents in rabbits. J Biomed Mater Res B Appl Biomater 2014;102:80-88.

25. Hokugo A, Sawada $Y$, Hokugo R, Iwamura H, Kobuchi M, Kambara T, et al.. Controlled release of platelet growth factors enhances bone regeneration at rabbit calvaria. Oral Surg Oral Med Oral Pathol Oral Radiol Endod 2007;104:44-48.

Received December 19, 2013 Accepted July 28, 2014 